\title{
THE ROLE OF GENERAL ATTORNEY IN ERADICATION OF CORRUPTION BY CORPORATION
}

\author{
Satya Marta Ruhiyat, Ismansyah, Nani Mulyati \\ Faculty of Law, Universitas Andalas \\ satyamarta.r93@gmail.com
}

\begin{abstract}
Considerable efforts have been made to fight corruption, however it continues to occur in Indonesia. In the present time, corruptions do not only carry out by individuals but also by corporations. However, the Criminal Code and Criminal Procedure Code do not recognize and regulate corporations as the subject of criminal acts, so that law enforcement officials, especially prosecutors, have difficulty in charging corporations. This paper tries to answer question about the role of prosecutors in the eradication of corruption by corporation based on The General Attorney Regulation Number: PER-028/A/JA/10/2014 on guidelines for prosecuting corporation. The research method employed is normative juridical method, where the data is analyzed with qualitative methodology. The General Attorney Regulation on Corporate Legal Subjects explains more apparent criteria for actions that can be attributed to the corporation. The regulation combines several theories of corporate criminal liability not only heavily rely on vicarious criminal liability theory. It also provides direction about the separation of corporate liability and director's liability. With this guideline, the public prosecutors have clearer direction to be able to charge the corporation so that it can restore the state finances that have been harmed by the corruption act.
\end{abstract}

Keywords: Corporate Criminal Liability; Corruption; General Attorney; Corporation

\section{Introduction}

The law must be able to overcome any problems that exist in society. One form of problems that continues to emerge and is disturbing the society is corruption. Literally corruption means decay, ugliness, depravity, dishonesty, can be bribed, immoral and deviations from holiness. ${ }^{1}$ Corruption is also interpreted as behavior that deviates from the official duties of a state office gains because of the status or money involving personal matters (individuals, close family, groups) or violating the rules of implementing some personal behavior, including ethical and moral issues in the public view. Therefore, corruption is currently in a very alarming phase in Indonesia. ${ }^{2}$ In the social sense it seems that the community does associate corruption as embezzlement of money (state or office) and accepts bribes in relation to position or occupation, even though from a legal standpoint it is not exactly the same; From a legal view many conditions or elements must be met for a behavior so it can be qualified as corruption. ${ }^{3}$ The definition of corruption is clearly stipulated in Law Number 20 of 2001 on Amendment to Law No. 31 of 1999 on Eradication of Corruption. It is said that every person (individual or

\footnotetext{
Imam Syaukani and Ahsin Thohari, Dasar-Dasar Politik Hukum (Jakarta: RajaGrafindo Persada, 2004$), 1$.

Widyo Pramono, Pemberantasan Korupsi dan Pidana Lainnya Sebuah Perspektif Jaksa dan Guru Besar. (Jakarta: Kompas Media Nusantara, 2016), 42.

3 Adami Chazawi, Hukum Pidana Korupsi di Indonesia (Jakarta: RajaGrafindo Persada, 2016), 2.
} 
corporation) who enriches himself or others illegally, and harms state finances. Especially for Indonesia, the approach of criminal law as an instrument in combating corruption is still preferable. $^{4}$

Globalization now causes corruption to continue and is increasingly difficult to prevent. The effects of globalization have made progress from various sectors including technology, communication, transformation and informatics, especially in the economic, trade and investment sectors. However, it needs to be realized that globalization and the development of science and technology besides creating benefits for humans, also bring negative effects, namely "globalization of crime" and increasing the quantity (number) and quality (modus operandi) of criminal acts in various countries and between countries.

Corruption is no longer only carried out by individuals but also can be committed by corporations. Corporate activities that aim to seek profits often lead them to do everything they can to achieve these goals. The effect is sometimes not directly felt by the community because of the ignorance of the community about corporate activities, especially in the development of the state infrastructure, what is seen by the public is the positive impact of the construction of the infrastructure, namely the economic situation that continues to increase.

Corporations according to Satjipto Rahardjo are bodies created and composed of corpus (body), to which the law gives an animus (soul) element that makes the body have a personality. Because this legal entity is a legal creation, then like its creation, law also determines its death. ${ }^{5}$ Furthermore, corporation according to criminal law is a group of people who are organized and have leaders and carry out legal actions, such as making agreements in the context of business activities or social activities carried out by the management for and on behalf of the organization. ${ }^{6}$

Corporations have important and strategic roles in modern life in the era of globalization. However, the important and positive role of the corporation in a country's economic growth is sometimes followed by violations of the criminal $\mathrm{law}^{7}$, accommodating the proceeds of crime, as

\footnotetext{
4 Ismansyah, "Penerapan dan Pelaksanaan Pidana Uang Pengganti dalam Tindak Pidana Korupsi," Jurnal Demokrasi 2, No. 2 (2007): 2.

5 Satjipto Rahardjo, Ilmu Hukum (Bandung: Citra Adi Karya, 2000), 13.

6 Eva Syahfitri Nasution, "Pertanggungjawaban Pidana Korporasi dalam Tindak Pidana Pencucian Uang," Marcatoria 2, (2015): 137.

7 Levina Yutitianingtyas, "Pertangunggungjawaban Pidana oleh Korporasi dalam Tindak Pidana Pelanggaran HAM di Indonesia," Novelty 1, (2016): 25.
} 
a means of committing a crime and obtain profits from criminal acts through the collective decisions of its managers. ${ }^{8}$

In its development then corporations are accepted to be criminal law subject because they are considered to be able to carry out legal acts or actions, including committing a crime. ${ }^{9}$ The consequence of corporations as the subject of criminal law means that corporations can commit criminal acts or fulfill the objective elements of an offense ${ }^{10}$, which can then be prosecuted for criminal liability. Corporate actions or activities are always carried out by or through human actions, therefore the ability to take responsibility for those who act for and on behalf of corporations is attributed to the corporation. ${ }^{11}$

In 2009-2010 PT. Duta Graha Indah (PT. DGI) through the main Director at that time made avicious agreement about the development projects for special infection and tourism hospitals of Udayana University. This agreement is made in order to win PT DGI as the executor (partner) that is contrary to the Presidential Decree Number 80 of 2003 on Guidelines for the Implementation of Government Goods / Services Procurement as amended several times with the latest Presidential Regulation Number 95 of 2007 along with the Technical Guidelines for Implementation. This action has resulted in enriching the corporations (PT. DGI) in 2009 at least Rp. 6,780,551,865 (Six Billion Seven Hundreds Eighty Million Five Hundred Fifty One Thousand Eight Hundred Sixty Five Rupiah) and in 2010 at least Rp. 17,998,051,740 (Seventeen Billion Nine Hundred Ninety Eight Million Fifty One Thousand Seven Hundred Forty Rupiahs). ${ }^{12}$

In addition, it also enriched M. Nazarudin and the corporations under his control of Rp. 10,290,944,000 (Ten Billion Two Hundred Ninety Million Nine Hundred Forty Four Thousands Rupiahs) so that this caused a loss of Rp. 25,953,784,580 (Twenty-Five Billion Nine Hundred Fifty Three Million Seven Hundred Eighty Four Thousand Five Hundred Eighty Rupiahs) as in the audit report in the context of auditing the calculation of state losses on cases of alleged corruption in infection and tourism special education hospital of Udayana University 2009-2010 fiscal year. $^{13}$

\footnotetext{
Budi Suhariyanto, "Urgensi Pemidanaan terhadap Pengendali Korporasi yang Tidak Tercantum dalam Kepengurusan," Yudisial 2, (2017): 240.

9 Tjandra Sridjaja Pradjonggo, "Alternatif Sanksi Pidana dalam Kejahatan Korporasi," Yustisia 80, (2010): 70.

10 M. Haryanto, "Pertanggungjawaban Pidana Korporasi dan Individualisasi Pidana," Refleksi Hukum (2012): 203.

11 Ridwan Rangkuti, "Pertanggungjawaban Korporasi dalam Tindak Pidana Lingkungan Hidup menurut UU No. 23 Tahun 1997," Justitia 2, (2014): 263.

12 Indonesia v. PT. DGI, Verdict of High Court of Jakarta No. 3/Pid.Sus -TPK/2018/PT.DKI.

13 Ibid.
} 
To date, it is not often for corporations to be put as suspects or defendants in corruption cases, especially those that harm the country's finances. The Criminal Code and Criminal Procedure Code do not recognize and regulate the corporation as a subject, so that the legal apparatus, especially the Public Prosecutor, has difficulty in making the criminal charges against corporation. However now the formulation of the indictment by the Public Prosecutor no longer refers to KUHAP but refers to the Attorney General's Regulation Number 028 / A / JA / 10/2014 on Guidelines for Subscribing to Criminal Cases with Corporation as Subjects as a specific and clearer rule.

The Attorney General's regulation is intended so that every Public Prosecutor who conducts investigations, not only focuses on individuals offender but also sees the extent to which corporations have liability in a corruption case so that state losses can be restored immediately. Based on this background, it is very interesting to scrutinize how is the role of the prosecutor in eradicating corruption against corporations in law enforcement efforts in Indonesia.

This study aims to examine, analyze and describe the role of prosecutors in eradicating corruption committed by corporations based on PERJA No: Per-028 / A / JA / 10/2014 on Guidelines for Subscribing to Criminal Cases with Corporation as Subjects. As for practically, this research can be used as an input material for law officials, judges and advocates in handling criminal cases of corruption committed by corporations.

\section{Methods}

This research adopts normative legal research method. In accordance with the problems studied, the approach used is the statute approach and the conceptual approach. This is a descriptive research which means describing data about a situation or social symptoms that develop in the midst of society so that the existence of this study is expected to obtain a comprehensive, complete and systematic picture of the object of research. ${ }^{14}$ The analytical method used is a qualitative analysis method. Qualitative analysis means that research is nonnumeric examination and interpretation of an observation, with the aim to find the meaning and pattern underlying the relationship. The data used is data that leads to studies that are theoretical in the form of principles, conceptions, views, legal doctrines, and legal methods

\footnotetext{
${ }_{14}$ Soerjono Soekanto, Pengantar Penelitian Hukum (Jakarta: Universitas Indonesia Pers, 1986), 10.
} 
relating to the theme of corporations, legal entities and business entities as subjects in the criminal law regime, which then analyzed qualitatively. ${ }^{15}$

\section{Result and Discussion}

\subsection{Eradication of Corruption Carried Out by Corporation}

Corporations as perpetrators of criminal offenses are not a new discussion in the crime prevention in Indonesia. The acceptance of the corporation as the subject of criminal law in Indonesia was first stated by the Emergency Law Number 17 of 1951 on Stockpiling of Goods, which in Article 11 of the Law explains that legal entities can be punished separately from their management. Corporations as criminal legal subject was then strengthened by the issuance of Emergency Law Number 7 of 1955 on Investigation, Prosecution of Economic Crimes, which in Article 15 of the Law explained that legal entities, companies, associations of people or foundations were legal subjects who could be convicted in criminal matters. At present more than one hundred laws outside the Criminal Code have put corporations as criminal subjects, including the Corruption Law which adopts the vicarious liability theory in the attribution of responsibility to corporation. ${ }^{16}$

In the process of modernization and economic development, reality shows that the development of corporations as actors of development plays a greater role. Corporate crime refers to crimes committed by corporations, for company interests by company officials such as bribery, illegal rebates, fraudulent competition, tax evasion, environmental pollution, discriminatory practices towards employees, illegal political contributions, product piracy and counterfeiting, sales dangerous products and so on. ${ }^{17}$

Doubts in the past to place corporations as subjects of criminal law that can commit crimes and be accounted for in the criminal law have now shifted. The establishment of corporations as offenders of criminal acts in criminal law seems to be an inevitable demand. This view overrides the old doctrine that corporations cannot be punished, "universities delinquere non-potest." This is evident in the process of drafting the Indonesian Criminal Code, because the drafters of the KUHP Bill have arrived at the stage of accepting and formulating corporations as subjects of criminal law and can be liable criminally. ${ }^{18}$

15 Earl Babbie, The Practice of Social Research (New York: Wadsworth Publishing Company, 1998).

16 Rasamala Aritonang, "Memidana Korporasi," Rubrik Opini Kompas. Desember 12, 2018.

17 Muladi, Pertanggungjawaban Pidana Korporasi (Bandung: PT. Alumni, 2013), 21.

18 Widodo Tresno Novianto, "Korporasi sebagai Subjek Tindak Pidana Korupsi dan Prospeknya Bagi 
Some of the bases to justify corporate criminal liability are: first, in a variety of economic and fiscal crimes, the profits obtained by the corporation or the losses suffered by the community can be so large that it will not be fair if the punishment is only imposed on the management alone. Second, by only convicting the management, there is no guarantee that the corporation will not repeat the crime again in the future, so that the punishment of the corporation can force the corporation to comply with the relevant regulations. ${ }^{19}$

According to Muladi (2012), there are at least seven main purpose of corporate criminal responsibility, namely: effective prevention of future deterrent effects, retribution, rehabilitation (both for corporations and criminal acts), a symbolic message that no crime is free from punishment, the moral condemnation of society, efficiency, predictability, and consistency with the principles of criminal law, and the most importantly justice. ${ }^{20}$

Legislation and legal cases in Indonesia tend to adopt vicarious criminal liability theory in imposing criminal liability for corporations. Vicarious liability is indeed the initial theory in accepting criminal liability for corporations. This theory is broad enough to be able to divert the responsibility of corporate managers regardless of their position within the corporation, becoming a criminal responsibility for the corporation. However, this theory is too broad and can be detrimental to the corporation, so there is also a need to limit the actions taken to provide benefits to the corporation or benefit to the corporate goal or be carried out in the context of tasks and management authority (intra-vires and scope of employment). So that the theory of vicarious criminal liability with more concrete criteria still needs to be maintained in the imposition of Indonesian corporate criminal liability. ${ }^{21}$

Based on the Law on the Eradication of Corruption, the formulation of the subject is using the words "person" as stipulated in Article 7 paragraph (3). This word according to Article 1 paragraph 3 means not only natural person but also corporation. The concept of person according to Satjipto Rahardjo, have a very central position, because all other concepts such as rights, obligations, mastery, legal relations, etc., ultimately are centered on the concept of person. This person as legal subject is the bearer of rights and obligations. ${ }^{22}$

Penanggulangan Korupsi di Indonesia," Majalah Yustisia 70 (2007): 4.

19 Rony Saputra, "Pertanggungjawaban Pidana Korporasi dalam Tindak Pidana Korupsi (Bentuk Tindak Pidana Korupsi yang Merugikan Negara TerutamaTerkait dengan Pasal 2 ayat (1) UU PTPK)," Jurnal Cita Hukum 2, (2015): 278.

20 Muladi, "Seminar Pertanggungjawaban Pidana Korporasi (Corporate Criminal Responsibility) dalam Kerangka "Legal Environement of Business" (2012).

21 Nani Mulyati, Pertanggungjawaban Pidana Korporasi (Depok: Rajagrafindo Persada, 2018), 333.

22 Satjipto Rahardjo, op., cit., p. 67. 
According to Article 20 of the Law on the Eradication of Corruption, corruption is carried out by corporations if the crime is carried out by corporate's members, based on work relations or other relationships, acting in the corporate environment, both alone and together. Corporate's members in this regulation are not limited to executives but also someone who has influence or authority in the corporation; regardless he or she has no formal position in the corporation. If the aforementioned persons commit deviations from the legal rules for or on behalf of the corporation and resulting in state or regional finances loss, then these actions can be qualified as criminal acts of corruption. Furthermore, if carried out on behalf of a corporation, criminal penalties can be imposed on the corporation and / or its management. ${ }^{23}$ It can be concluded that this regulation adopts vicarious criminal liability theory as foundation to attribute criminal liability to the corporation. Where actusreus and mensrea of the management can be pulled into actusreus and mensrea of the corporation based on the attribution and delegation theory.

However, there is an obscure resulted from this regulation about subjective liability. Article 20 paragraph 1 stated that in the case of a criminal act of corruption carried out by or on behalf of a corporation, then the prosecution and imposition of criminal sanction can be carried out by the corporation and / or its management. According to the authors, it is erroneous to see corporation and its managements as the same person. Corporation is an independent legal subject that is separate and different from the management. Based on the subjective liability in criminal law, which states that only the criminal offender and guilty person can be liable in criminal law. ${ }^{24}$ It is unacceptable to be punished before proven in a trial. It is impossible then if the one who committed a crime is $\mathrm{A}$, but the one who is convicted is $\mathrm{B}$, or the one who committed a crime and is charged is A, but the one who is convicted is B. Article 20 paragraph (1) mixes the corporation with corporate management in prosecution and criminal charges. This stipulation then creates chaos in the implementation of corporate criminal liability by the law enforcement officials namely judges, police and public prosecutors.

\subsection{General Attorney's Role in Eradicating Corruption Cases}

General Prosecutors have an important role in combating corruption in Indonesia. Prosecutors are government institutions that carry out state power in the field of prosecution. According to Article 26 of Law No. 20 of 2001 jo. Law No. 31 of 1999 on the Eradication of Corruption confirms that investigations, prosecutions and examinations in court proceedings

23 Chaerul Anwar, Kejaksaan Memberantas Korupsi (Jakarta: Dealeder, 2014), 148.
Nani Mulyati, op., cit. 
against criminal acts of corruption are carried out based on the applicable criminal procedure law, unless otherwise stipulated in the regulation.

Handling corruption cases carried out by the Prosecutor's Office have been one of the main missions and are a main task that must be succeeded, in line with the demands of reform in the field of law enforcement in Indonesia. Various policies and instructions have been issued by the Attorney General's Office to encourage and increase the effectiveness of handling corruption cases.

Initial step in criminal procedure is investigation. Investigation is a series of actions by the investigator to search for and collect evidence and find the suspect. This also applies to the investigation of special crimes. ${ }^{25}$ Sudono Iswahyudi affirms that investigations role of the Public Prosecutors are stipulated in many regulations: ${ }^{26}$ (1) Article 284 (2) KUHAP jo. Article 17 President Decree No. 27 Year 1983 on the Implementation of the Criminal Procedure Code; (2) TAP MPR RI No. XI/MPR/1998 on State's Management that is Clean and Free of Corruption, Collusion and Nepotism jo. President Instruction No. 30 year 1998 date 2 December 1998 on Eradication of Corruption, Collusion and Nepotism, which contains, among others: The President instructed the Attorney General to immediately take proactive, effective and efficient actions in combating corruption, collusion and nepotism in order to streamline and improve the implementation of national development in order to actualize the national goals of the Indonesian nation; (3) Law No. 28 year 1999 date 19 May1999 on The implementation of a Clean and Free State of KKN, which includes among others the authority of the Prosecutor as Investigator listed in Articles 1, 12, 17, 18, 20, 21 and 22 along with the explanation; (4) President Decision No. 86 year 1999 date 30 July 1999 on Organizational Structure and Work Procedure of the Prosecutor's Office in which Article 17 states: "The Deputy Attorney General for Special Crimes has the duty and authority to conduct investigations, additional examinations, prosecutions, implementation of judges' decisions and court decisions, oversight of the implementation of conditional decisions and other legal actions regarding economic crimes, corruption and other special crimes based on legislation and policies stipulated by the Attorney General."; (5) Article 27 of Law No. 31 year 1999 date 16 August 1999 on the Eradication of Corruption.

\footnotetext{
25 The General Attorney of Indonesia, Diklat Tahap-Tahap Penyidikan dan Teknik Pelaksanaannya (Jakarta: Direktorat Penyidikan Bidang Tindak Pidana Khusus Kejaksaan Agung, 1987), 7.

26 Sudono Iswahyudi, "Strategi Pemberantasan Korupsi di Indonesia, Keterkaitan KPK dengan Kejaksaan dalam Penanganan Tindak Pidana Korupsi" Media Hukum 2, No 8 (2003).
} 
Therefore it can be concluded that the General Attorney has authority not only in the case of prosecution as described in the Criminal Procedure Code, but also has the authority to carry out investigations in corruption cases. The Attorney General's Office is very serious in the eradication of corruption. The Attorney General's Office assessed that there were many state losses arising from corruption, especially if it is committed by the corporation. State's financial loss caused from corruption by corporation is much bigger than corruption committed by individual person. Therefore at the moment Prosecutor has begun to give more attention to corporation as criminal offender, particularly in corruption cases.

In the event that the investigator has investigated a crime, after the evidence has been collected and the suspect have been found, the investigator carefully assesses whether there is enough evidence to transfer the case to the public prosecutor. If the investigator concludes that the case can be continued, the investigator notifies the prosecutor with the Notice of Commencement of Investigation (SPDP) in accordance with Article 109 paragraph (1) of the Criminal Procedure Code.

Yahya Harahap affirms that the Public Prosecutor is an official who is authorized by law as a public prosecutor and implements the decision of the judge who has obtained permanent legal force. ${ }^{27}$ The function of Attorney General in the prosecution process is regulated in various laws and regulations as follows: (1) Article 1 paragraph 6, letter b and Article 13 of Law No. 8 of 1981 on the Criminal Procedure Code, which state that the public prosecutor is a Prosecutor authorized by this Act to prosecute and carry out the judgment of the court; (2) Article 1 paragraph 2 of Law No. 16 of 2004 on the Indonesian Prosecutor's Office; (3) Article 1 paragraph 9 of Law No. 11 of 2012 on the Juvenile Justice System; (4) Article 14 of Law No. 5 of 1983 on the Indonesian Exclusive Economic Zone which state that the public prosecutor is a Prosecutor at the District Court.

The main tasks and functions of the Prosecutor's Office in the field of corruption prosecution in the form of investigation, prosecution, execution and examination as well as other duties, are carried out by the Special Crimes Division, under the control of the Deputy Attorney General for Special Crimes who is responsible to the Attorney General.

The Eradication of corruption has been mandated by the government to the prosecutor's office. Law enforcement actions and strategies directed at the Eradication Corruption Policy is stated in Presidential Instruction No. 5 of 2004 on the Acceleration of the Eradication of

27 M. Yahya Harahap, Pembahasan Permasalahan dan Penerapan KUHAP Jilid I (Jakarta: Pustaka Kartini, 1985), 387. 
Corruption. In this case the President specifically instructed the Deputy Attorney General for Special Crimes to: optimize investigative and prosecution efforts against corruption in order to punish perpetrators and save state money; prevent and provide strict sanctions against abuse of power and authority carried out by public Prosecutors in the context of law enforcement; Increase cooperation with the Indonesia National Police, Development Financial Examining Body (BPKP), Financial Transaction Reports and Analysis Center(PPATK) and State Institutions related to law enforcement efforts in restoring state financial losses due to criminal acts of corruption.

Prosecutors in an attempt to rescue state finances in corruption are regulated in Article 273 of the Criminal Procedure Code which state that: (1) if a court judgment imposes fine on the convicted, he/she is given a period of one month to pay the fine except in a quick examination decision; (2) in the event that there are strong reasons, the period referred to in paragraph (1) may be extended for a maximum of another one month; (3) If the court judgment also stipulates that the evidence is confiscated for the state, in addition to the exception as stated in Article 46, the Prosecutor authorizes the object to the state auction office and for three months to sell at the auction, the proceeds of which are put into state treasury for and on behalf of the Prosecutor ; (4) The period in paragraph (3) is extended for a maximum of another one month.

Subscriptions for corruption cases carried out by the Prosecutor's Office have been one of the main missions and are the main tasks that must be succeeded, in line with the demands of reform in the field of law enforcement in Indonesia. Various policies and instructions have been issued by the Attorney General's Office as efforts to encourage and increase the intensity and quality of handling corruption cases. The Attorney General's Office has processed several cases in eradicating corruption, especially those committed by corporations. The following is the data on the results of the Public Prosecutor's work in an effort to eradicate criminal acts of corruption committed by the Corporation.

Table 1.

Types of Corruption Cases by Corporations Handled by the Attorney General's Office of the Republic of Indonesia

\begin{tabular}{|c|c|c|c|c|}
\hline Corporation & Case & State Financial & Inspection Phase & \\
\hline PT. Giri Jaladhi Wahana & 2009 & 7,6 Billion & $\begin{array}{lrrr}\text { Verdict of the } & \text { Supreme } & \text { Court } \\
\text { 936K/Pid.Sus/2009. } & & \end{array}$ & No: \\
\hline PT. Asian Agri Group & 2011 & 1,29 Trillion & $\begin{array}{l}\text { Verdict of the } \\
\text { No:2239K/Pid.Sus/2011 }\end{array}$ & Court \\
\hline
\end{tabular}




$\begin{array}{lcll}\begin{array}{l}\text { PT. Cakrawala } \\ \text { Nusadimensi }\end{array} & 2011 & \text { 4,189 Billion } & \begin{array}{l}\text { Verdict of District Court of Bandung No: } \\ \text { 65/Pid.Sus/TPK/2011/PN.Bdg }\end{array} \\ \begin{array}{l}\text { PT. Green Planet } \\ \text { Indonesia }\end{array} & 2012 & \text { USD 270 Million } & \begin{array}{l}\text { Verdict of District Court of Centre of Jakarta } \\ \text { No: 85/Pid.Sus/TPK/2012/PN.JktPst }\end{array} \\ \text { PT. IM2 } & 2015 & \text { 1,3 Trillion } & \begin{array}{l}\text { Verdict of the Supreme Court } \\ \text { No:77K/Pid.Sus/2015. }\end{array} \\ \text { PT. Sinar Medow } & 2018 & \text { 4,6 Billion } & \begin{array}{l}\text { At the Stage of Investigation by the Prosecutor's } \\ \text { Office }\end{array} \\ \text { PT. Zebit Solution } & 2018 & \text { 14 Billion } & \begin{array}{l}\text { At the Stage of Investigation by the Prosecutor's } \\ \text { Office }\end{array}\end{array}$

Source: Collection of Case Data compiled by Writers from several media sources and the Attorney General's Office.

Based on the table above, it can be concluded that the Attorney General's Office has made quite aggressive efforts in dealing with corporate cases carried out by corporations since 2009 and has increased the number in 2018. In addition, it can also be seen from the table that state losses arising from corruption committed by the company is very big amount of money. Prosecutors are required to continue to synergize and focus on resolving corporate corruption cases in Indonesia.

Many efforts are carried out by the Attorney General's Office to open, search and resolve the problems of corruption committed by corporations. In addition to Attorney General's Regulation Number: PER-038 / A / JA / 10/2010 concerning Administrative and Technical Administration of Special Crime Cases, there is a new breakthrough issued by the Attorney General in resolving criminal acts are carried out by the Corporation, Attorney General Regulation (PERJA) Number: PER-028 / A / JA / 10/2014 concerning Guidelines in Handling Criminal Cases with Corporation as Criminal Subjects.

PERJA is issued to help the Public Prosecutors to process corporations that commit criminal acts, especially corruption cases and procedures for imposing criminal liability on corporations. In the explanation of the PERJA rules in the appendix, it is explained in detail what actions can be held for the corporation liability, namely: ${ }^{28}$ (1) Actions based on the decisions of the corporate management who do and participate in doing criminal act; (2) Acts for the corporation, did by someone in relation with the corporation, because of work relationship and / or other relationships; (3) Actions that use human resources and / or any other form of support and facilities from the corporation; (4) Actions carried out by third parties at the request or order Peraturan Jaksa Agung RI Nomor: PER-028/A/JA/10/2014 tentang Pedoman Penangganan Perkara Pidana
dengan Subjek Hukum Korporasi, lampiran p. 3-4. 
of the corporation and / or corporate management; (5) Actions in the context of carrying out the daily business activities of the corporation; (6) Actions that benefit the corporation; (7) Actions received / usually accepted (accepted) by the corporation; (8) Corporations that actually accommodate the results of criminal acts; (9) Other acts that can be held accountable to the corporation according to the law.

In this rule the determination of the corporation as the subject of criminal law does not strictly adopt one of the corporate criminal liability doctrine. PERJA adheres to vicarious criminal liability, identification, and also the corporate culture doctrine. This stipulation is deemed appropriate to provide wider space in the attribution of criminal liability for corruption. Besides, PERJA is considered to be able to identify clearer criteria about when a corporation can be liable in criminal law. Further, PERJA is considered as a step forward for the Public Prosecutor to charge not only individual perpetrators but also corporations.

Furthermore, PERJA has also explicitly distinguished the corporate criminal liability and the management's liability when criminal acts occurred within the corporation. PERJA about the Subject of Corporation in the appendix explains some criteria for accounted management actions for criminal liability, namely: (1) Every person who commits, participates, orders, and recommends to commit or help to commit a crime; (2) Every person who have the control and authority to take preventive actions but do not take such actions, and realize that there is a considerable risk with the omission; (3) Every person who has knowledge of a substantial risk, suffices if he knows that the crime is committed by the corporation.

This stipulation is a step forward in eradicating corruption carried out by corporations, because as mentioned above, Article 20 paragraph 1 of the Law on the Eradication of Corruption stated a fatal flaw by confusing corporate subjects with individual subjects. Thus, the existence of PERJA provides clarity for public prosecutors to be able to distinguish criminal liability for the corporation and for the corporate management if the crime occurs within the corporation.

Additionally, the PERJA provides guideline for the public prosecutors about how to investigate, prosecute and execute the decisions for the corporations as criminal offenders. Thus, the function of the prosecutor as the rescue of state finances can work so that the society are able to trust the prosecutor in carrying out their duties in order to create justice and better law enforcement in Indonesia.

The PERJA also provide corporation that can be sued is Corporation; Corporations that are transferred or taken over; Group corporation which is a collection of people or entities that are 
related to ownership, management, and / or financial relations; and Corporations that are still in bankruptcy process. Moreover, towards corporations can only be charged with criminal penalties and additional penalties and / or disciplinary actions. Additional penalties and disciplinary actions imposed on corporations and corporate administrators include: Payment of replacement money to state finances; Deprivation or elimination of profits obtained from criminal acts; Repair of damage caused by a crime; Obligation to do what is done without rights; Placement of companies under the custody for a certain period of time; Closing or freezing some part or all of the company's activities for a certain period of time; Revocation of some or all certain rights; Revocation of business license; Deprivation of evidence or assets / assets of the corporation; Other actions in accordance with applicable laws and regulations.

Additionally, PERJA also provides that if the penalties in the form of substitute money imposed on corporations, is unable to be paid within 30 (thirty) days, assets of the company can be confiscated to fulfill payment of substitute money, if the corporation does not have enough assets, the corporation is charged with additional penalties listed before. This stipulation is also applicable to fine. Moreover, PERJA stipulates that charge against bodies that are not incorporated, then the management is charged with imprisonment, fines or additional criminal penalties.

Therefore, with clearer stipulations the prosecutor's office is able and must be courageous to impose corporate criminal liability in corruption cases. So that law enforcement in Indonesia in the context of eradicating corruption must continue to advance and be more innovative in imposing criminal penalties not only to punish people (natural beings) but can also be imposed on corporations. With immediate aim is the prosecutor's office able to restore state finances that have been taken by the corruption act.

\section{Conclusion}

The role of the prosecutors in convicting the corporation is referring to PERJA Number: PER-028 / A / JA / 10/2014 concerning Guidelines for Subscribing the Subject of Corporation. Based on the PERJA all forms of investigations, prosecutions, implementation of court decisions can be used as a basis for prosecutors in ensnaring corporations. By combining the theory of identification, vicarious criminal liability and corporate culture, in corruption cases committed by corporations, the public prosecutor is able to convict corporations so that the prosecutor's 
office can immediately restore the state finances loss that have been taken from the criminal acts of corruption committed by the corporation.

However, it is also very important that the prosecutors to be providedwith special training on handling corruption cases committed by corporations, especially by examining in depth about PERJA Number: PER-028 / A / JA / 10/2014 while also referring to PERJA Number : PER-038 / A / JA / 10/2010 on Administrative and Technical Administration of Special Crime Cases so that the prosecutor's office is knowledgeable and considered to process corruption case with the immediate aim to restore state finances from criminal acts of corruption committed by corporations.

\section{References}

Anwar, C. Kejaksaan Memberantas Korupsi. Jakarta: Dealeder, 2014.

Aritonang, R. "Memidana Korporasi." Rubrik Opini Kompas, Desember 12, 2018.

Babbie, Earl. The Practice of Social Research. New York: Wadsworth Publishing Company, 1998.

Chazawi, A. Hukum Pidana Korupsi di Indonesia. Jakarta: RajaGrafindo Persada, 2016.

Harahap, M.Y. Pembahasan Permasalahan dan Penerapan KUHAP Jilid I. Jakarta: Pustaka Kartini, 1985.

Haryanto, M. "Pertanggungjawaban Pidana Korporasi dan Individualisasi Pidana." Refleksi Hukum, (2012).

Indonesia v. PT. DGI. Verdict of High Court of Jakarta No. 3/Pid.Sus- TPK/2018/PT.DKI, (2018).

Ismansyah. "Penerapan dan Pelaksanaan Pidana Uang Pengganti dalam Tindak Pidana Korupsi." Jurnal Demokrasi 2, No. 2 (2007): 2-15.

Iswahyudi, S. "Strategi Pemberantasan Korupsi di Indonesia, Keterkaitan KPK dengan Kejaksaan dalam Penanganan Tindak Pidana Korupsi." Media Hukum 2, No. 8 (2003).

Kejaksaan Agung RI. Diklat Tahap-Tahap Penyidikan dan Teknik Pelaksanaannya. Jakarta:

Direktorat Penyidikan Bidang Tindak Pidana Khusus Kejaksaan Agung, 1987.

Muladi. Pertanggungjawaban Pidana Korporasi. Bandung: Alumni, 2013.

."Seminar Pertanggungjawaban Pidana Korporasi (Corporate Criminal Responsibility)

Dalam Kerangka "Legal Environment of Business", (2012).

Mulyati, N. Pertanggungjawaban Pidana Korporasi. Depok: Rajagrafindo Persada, 2018. 
Nasution, E.S. "Pertanggungjawaban Pidana Korporasi dalam Tindak Pidana Pencucian Uang." Marcatoria 2, (2015): 135-148.

Novianto, W.T. "Korporasi sebagai Subjek Tindak Pidana Korupsi dan Prospeknya Bagi Penanggulangan Korupsi di Indonesia." Majalah Yustisia 70, (2007): 4-16.

Pradjonggo, T.S. "Alternatif Sanksi Pidana dalam Kejahatan Korporasi."Yustisia 80, (2010): 6878.

Pramono, W. Pemberantasan Korupsi dan Pidana Lainnya Sebuah Perspektif Jaksa dan Guru Besar. Jakarta: Kompas Media Nusantara, 2016.

Rahardjo, S. Ilmu Hukum. Bandung: Citra Aditya Bakti, 2014.

Rangkuti, R. "Pertanggungjawaban Korporasi dalam Tindak Pidana Lingkungan Hidup menurut UU No. 23 Tahun 1997." Justitia 2, (2014): 262-275.

Saputra, R. "Pertanggungjawaban Pidana Korporasi dalam Tindak Pidana Korupsi (Bentuk Tindak Pidana Korupsi yang Merugikan Negara Terutama Terkait dengan Pasal 2 ayat (1) UU PTPK)." Jurnal Cita Hukum 2, (2015): 263-275.

Soekanto, S. Pengantar Penelitian Hukum. Jakarta: Universitas Indonesia Pers, 1986.

Suhariyanto, Budi. "Urgensi Pemidanaan terhadap Pengendali Korporasi yang Tidak Tercantum dalam Kepengurusan." Yudisial 2, (2017).

Syaukani, Imam, and Ahsin Thohari. Dasar-Dasar Politik Hukum. Jakarta: RajaGrafindo Persada, 2004.

Yutitianingtyas, L. "Pertangunggungjawaban Pidana oleh Korporasi dalam Tindak Pidana Pelanggaran HAM di Indonesia." Novelty 1, (2016): 25-40. 